\title{
The difference between pollen types and plant taxa: a plea for clarity and scientific freedom
}

\author{
Pim de Klerk \& Dr. Hans Joosten ${ }^{*)}$
}

Keywords: palynological methods, pollen morphology, pollen type nomenclature

\begin{abstract}
This paper discusses the character of pollen types. We argue that pollen types and plant taxa are completely different entities (morphological and taxonomical respectively) and therefore should be treated and displayed differently. Common problems in conventional pollen type nomenclature are illustrated with examples from present day European palynological practice. We plead for clarity in pollen type nomenclature and for the scientific freedom to use 'unconventional' methods to avoid confusion.
\end{abstract}

\section{[Der Unterschied zwischen Pollentypen und Pflanzentaxa: Ein Plädoyer für Deutlichkeit und wissen- schaftliche Freiheit]}

Zusammenfassung: Dieser Artikel diskutiert den Charakter von Pollentypen. Wir argumentieren, dass Pollentypen und Pflanzentaxa komplett unterschiedliche Entitäten (morphologische bzw. taxonomische) sind, und deswegen unterschiedlich behandelt und dargestellt werden sollten. Allgemeine Probleme der konventionellen Nomenklatur von Pollentypen werden anhand von Beispielen aus der europäischen palynologischen Praxis illustriert. Wir plädieren für Deutlichkeit in der Nomenklatur von Pollentypen und für die wissenschaftliche Freiheit, ,unkonventionelle' Methoden zu benutzen, um Verwirrung zu vermeiden.

\section{Introduction}

Recently, a debate arose between the first author of this paper and the previous editor of Eiszeitalter und Gegenwart on the display of pollen type names. In a submitted article (DE KLERK 2004a) pollen type names were displayed in SMALL CAPITALS in order to distinguish them clearly from names of plant taxa, as we had proposed earlier in a major international palynological journal (Joosten \& De KLeRK

* Anschrift der Verfasser: P. DE KLERK Staatliches Museum für Naturkunde Karlsruhe, Erbprinzenstraße 13, D-76133 Karlsruhe, Germany; pimdeklerk@web.de

Dr. H. Joosten Institute of Botany and Landscape Ecology, Ernst-Moritz-Arndt University, Grimmer Straße 88, D-17487 Greifswald, Germany; joosten@uni-greifswald.de
2002). The referees of the manuscript provided many valuable comments, but formulated no criticism on this display of pollen type names, indicating that they - although not necessarily agreeing with it - at least permitted it. Only in the stage of printing, the display was prohibited by the editorial board because it "violated the common practice of the journal". We were invited, however, to present our viewpoints in a paper.

Also other journals have recently refused the use of SMALL CAPITALS for pollen type names against the wishes of the authors (e.g. KAFFKE \& Kaiser 2002, Lorenz \& Schult 2004, JoosTEN \& DE KLERK 2007a, b) because this would be a "violation of internationally established and applied rules", because "the usual conventions were preferred", or without giving any reasons at all.

For outsiders, the issue might appear a debate on merely typography. To our opinion, howe- 
ver, there are such distinct differences between pollen types and plant taxa, that they should not be treated as equivalents: the display of pollen type names is a scientific, not a typographic theme.

The present paper summarises our viewpoints and conclusions, pleas for scientific freedom, and invites the scientific audience to participate in the discussion. For pollen morphological reference, we use the main central/western European pollen identification keys of FÆGRI \& Iversen (1989), Moore et al. (1991), Beug (2004), and the Northwest European Pollen Flora (Punt 1976, Punt \& Clarke 1980, 1981, 1984, Punt et al. 1988, 1995, 2003, Punt \& Blackmore 1991). Although Fægri \& Iversen (1989) systematically abbreviate the suffix 'type' with t., we write this in full in order to prevent confusion. We use the term 'pollen' to represent both pollen and spores of vascular plants and bryophythes (cf. 'sporomorphs' sensu ERdTMAn 1947). We use small CAPitals for pollen type names, to make our point clear.

\section{Plant taxa and pollen types}

Plant taxa are botanical objects. Their features have been described in great detail in taxonomic studies according to scientific methods that have developed over centuries since the work of Linnaeus (cf. STAFLEU \& CowAN 1976). Of all described plant taxa, type specimens exist in plant herbaria that can always be studied in order to check the original descriptions and features (cf. Holmgren et al. 1990). The features are also described elaborately in flora works that allow taxonomical identification of plants. Whereas plant taxonomy is the science of classifying plants, the naming of plants (i.e. plant nomenclature) is a different (although closely related) discipline with its own rules and conventions (cf. Greuter et al. 2000).

Pollen grains are produced by plants and, thus, are also botanical objects. Since all plants produce their own genetically distinct pollen, in theory all pollen grains can (with modern genetic techniques) be attributed to a specific plant species, and even - except for clones - to individual plants. In common palaeopalynological praxis that focuses on the properties of the pollen wall that are maintained in fossil conditions, this is not possible because many plant taxa produce pollen grains whose pollen walls morphologically resemble each other to such extent that a differentiation can not be made with standard light-microscopy. One would expect that taxonomically related plants would produce morphologically similar pollen grains. Indeed this is largely the case with some families like the Poaceae, the Rubiaceae, and the Chenopodiaceae and Amaranthaceae (cf. FÆGRi \& Iversen 1989, Moore et al. 1991, Beug 2004), but it is certainly no general phenomenon. The family Polygonaceae, for example, comprises species with highly diverse pollen (cf. Punt et al. 1988). Other families produce predominantly uniform pollen types but include some species with completely deviant types, whereas also the opposite occurs that pollen grains with much morphological resemblance are produced by taxonomically totally unrelated species (for examples see Joosten \& DE KLERK 2002: 32). It is, thus, principally impossible to identify taxonomical relationships between large sets of plant species solely on the base of pollen morphology.

Pollen morphologists describe morphological features of pollen grains to classify pollen. There are basically two approaches to morphological pollen classification (cf. BIRKS \& BIRKS 1980). "Intrinsic" classification departs from the morphological properties of pollen grains independent of their taxonomical relationships, and therefore merely classifies a collection of morphological objects (cf. "formtaxa"). Such an approach is applied by e.g. IVERSEN \& Troels-Smith $(1950,1980)$ and VAN DeR HAMmEN (1956) and proved valuable for preQuaternary palynology where a relation to the producing taxa is absent or only assumed. "Extrinsic" classification departs from actual, correctly identified, plant taxa from which the pollen morphological properties are described. The latter results in "taxomorphological" pollen types for which there is no doubt from which plant species the pollen originates. This approach is used in most identification keys for Quaternary pollen: these are not based on fossil pollen but on palynomorphic studies of present-day plant material. Contrary to the de- 
scriptions of plant taxa, there are normally no pollen morphological "type" examples of the described taxomorphological pollen types.

Quaternary palaeopalynologists, who study fossil pollen, do not classify but identify pollen. They identify an observed fossil pollen grain as belonging to a specific morphological category that is subsequently attributed to a specific taxomorphological pollen type known from the pollen morphological literature. In this way the observed pollen types are directly translated into known plant taxa. The advantage of this practice is that all ecological information about the plant taxa that were studied pollen morphologically to classify the taxomorphological types can directly be applied to the observed fossil pollen.

There are, however, many possible defective links between fossil pollen types and actually existing plant taxa (Joosten \& De KLeRK 2002):

1: There is no strict connection between pollen morphological types and plant taxa (as illustrated above).

2: Pollen morphological literature is incomplete and does not provide the full palynomorphological diversity of the native flora of a study area: plant taxa might exist that produce pollen grains similar to that of other plant taxa without it being known. This not only applies to regions in the world where pollen morphological inventory is still in its infancy (cf. HoOghIEMSTRA \& VAN GeEl 1998), but even applies to Northwestern Europe. The Northwest European Pollen Flora, the worlds most detailed pollenmorphological study, still covers only around 55 out of 130 families, and ca. 600 species out of 2500 species present in the study area (JoOsten \& De Klerk 2002). Beug (2004) studied pollen of 2500 plant species, but distinguishes conspicuously less morphological types per family than the Northwest European Pollen Flora.

3: The fossil pollen may originate from another collection of species than has been used for taxomorphological classification in e.g. a pollen flora. Such "exotic" pollen is attributable to long-distance transport (by air, flowing water, driftwood, animals, or humans), erosional redeposition, and contamination (cf. e.g. IVERSEN 1936, Scamoni 1955, Vuorela 1972, Van Der
Woude 1983, Van der KnaAp 1987, Huelmroos 1991, Joosten \& VAN den Brink 1992, HJelmroos \& Franzén 1994, De Klerk et al. 1997, LAURSEN et al. 1997, for further references see Joosten \& De Klerk 2002: 32-33). There is no problem when the exotic pollen is unambiguously recognized as such, e.g. pollen attributable to thermophillous plant taxa in Lateglacial sections (cf. IVERSEN 1936). Pollen of an extinct taxon, however, might be easily ascribed to a too small set of taxa if redeposition remains unnoticed, e.g. pollen of Restionaceae (a family that became extinct in Europe) as that of the pollen morphologically similar Poaceae (cf. Chanda \& ERdtman 1965). Another example of erroneous linkage of palynomorphological objects and plant taxa is when non-pollen palynomorphs are mistaken for pollen grains, e.g. the confusion between JUNIPERUS pollen and certain algal and bryophyte spores (MOoRE 1980), the confusion between pollen of Lemna and similar-looking moss spores (cf. Bóros \& JÁRAI-KOMLODI 1975), or the identification of Spirogyra-like spores as MAGNOLIA pollen (VAN Geel \& Grenfell 1996).

4: Corrosion, degradation, and mechanical damage of pollen grains might proceed to such degree, that unambiguous identification is impossible and that confusion with other pollen morphological entities might occur (for examples see Joosten \& De KlerK 2002: 34).

There are, therefore, significant differences between the concepts of 'plant taxa' and 'palynomorphological types'. It is impossible to ascribe fossil pollen beyond any doubt to a recent and native plant taxon that produces the same pollen type. Assignment of fossil pollen to a taxon is, therefore, not a matter of identification, but of interpretation, and it is a serious scientific error to treat pollen types and plant taxa as identical and their names as synonyms, as is unfortunately not infrequently done in palynological papers.

\section{Conventions in pollen type nomenclature}

There are clear rules that regulate plant taxonomical nomenclature (cf. GREUTER et al. 2000). For pollen type nomenclature such rules do not exist. Berglund \& Ralska-Jasiewiczowa 
(1986: 457) propose that "The taxonomic nomenclature in pollen diagrams should follow international standards, e.g. in Europe the Flora Europaea nomenclature is to be recommended". This assumes that pollen types and plant taxa can be treated as being identical, which we think is wrong (argued above).

A proposal for pollen type nomenclature was formulated as 'Suggestions for students of plant microfossils' at a conference in Bromma (Sweden) in 1950 by some of the leading palynologists of that time: K. FÆGRI, R. POTONIÉ, O. Selling, G. Erdtman, and J.M. Schopf. These 'suggestions' were only informally distributed: publication in an international journal only happened many years later (STAFLEU 1967: 26, JoosTEN \& De KLERK 2002: 36). BiRKS (1973: $225-$ 226) and BIRKS \& BIRKS (1980: 24; cf. BERGLUND \& Ralska-Jasiewiczowa 1986: 457-460, JoosTEN \& DE KLERK 2002: 37) present some 'conventions' how these suggestions should be used in practice. These include a.o. that pollen types should be named after plant taxa that are known to produce these pollen types. Pollen types that are known to be produced by only one species should be named after this species; if a complete family produces pollen grains that cannot be morphologically distinguished, the type should be named after the family. If a pollen morphological category is known to be produced by two taxa, it should be named after these two taxa. If three or more plant taxonomical entities - but not all entities within the same taxonomical rank - are known to produce the same morphological pollen type, the suffix 'type' should be added after the taxonomical name.

There are several basic problems connected with these conventions (cf. JoOSTEN \& DE KLERK 2002), e.g.

1: they do not provide a naming procedure for pollen types from which it is unknown by which taxa they are produced and for pollen types that are identified with a reference collection of limited extent,

2: identical pollen types obtain different names in different regions when they are named after the most likely producing plant taxon,

3: the name of a type has to change when an additional taxon is discovered to produce the same pollen type,
4: pollen type names should also immediately change when plant taxonomical and/or nomenclatural viewpoints change, and

5: using bare taxon names for pollen type names violates a basic rule in terminology, i.e. that different objects should not be expressed with the same term.

Next to these theoretical objections, there is the practical problem that the 'suggestions' and 'conventions' are not consistently followed in pollen morphological handbooks, even when these claim to do so (FÆGRI \& IVERSEN 1989, Moore et al. 1991, Beug 2004). For example, Fægri \& Iversen (1989) and Moore et al. (1991) describe a GALIUM TYPE that is known to be produced by all genera of the Rubiaceae family, and thus should have been properly named Rubiaceae (cf. Beug 2004). A name for a pollen morphological entity that completely deviates from a plant taxonomical name is the WILD GRASS GROUP of MoOre et al. (1991, following ANDERSEN 1979). The requirement that a pollen type should be named after two taxonomical entities when it is known to be produced by two such entities is violated by FÆGRI \& IVERSEN (1989) who have a CHENOPODIACEAE of which it is mentioned that it is also produced by Amaranthaceae taxa, and thus would have been more properly named CHEnopodiaceae and Amaranthaceae (cf. Moore et al. 1991). Furthermore FÆGRI \& IVERSEN (1989) forget to mention that not all members of the family Chenopodiaceae produce their Chenopodiaceae pollen type (as the name would suggest), but they do present a separate Polycnemum/Paronychia type that is produced by some Chenopodiaceae species (cf. BeUG 2004 who presents the type CHENOPODIACEAE P.P., Amaranthus that excludes pollen produced by the genus Polycnemum).

The Northwest European Pollen Flora uses a totally different nomenclatural system in that all pollen morphological categories in the main key are named "type". This concept of "type", thus, completely differs from the "type" concept of the 'conventions'. In the subkeys, i.e. at a lower hierarchical level, "groups" are distinguished that consist of morphologically less distinct categories within a type known to be produced by several plant taxa, whereas no suf- 
fix is added when such a subsidiary category is known to be produced by only one (northwest European) taxon. In the UMBELLIFERAE key of Punt \& Clarke (1984), for example, the OENANthe fistulosa type consists of the Oenanthe aquatica Group, the Oenanthe PEUCEDANiFoLIA GROUP, the OENANTHE CROCATA GROUP, and Oenanthe fistulosa, whereas Cicuta virosa TYPE pollen is only known to be produced by Cicuta virosa.

Another concept of ,group“ is used in the key of FÆGRI \& IVERSEN (1989), which has e.g. the VACCINIUM GROUP including several types produced by Ericaceae taxa. FÆGri \& Iversen (1989) are, however, not consistent in using the suffix "group" for a collection of types. Their CAREX TYPE, for example, includes the DULichium TYPE and the ERIOPHORUM TYPE and thus uses an identical addition "type" for hierarchically different and nested morphological levels. BEUG (2004) uses the "group" in two different ways, firstly as a collection of morphologically related types, e.g. the Aconitum-GrupPe encompassing an Aquilegia-Typ, an Aconitum-Typ, and a Consolida-Typ, and secondly as a residual collection of morphologically completely different types that do not key out in the main key, e.g. the Sorbus-GrupPe, "summarising 13 genera of Rosaceae with distinct variable characteristics, and Lycium" (Beug 2004: 278; original text in German).

These examples and considerations clearly demonstrate that a common widely applicable pollen morphological nomenclature does not exist. Conventions in pollen type nomenclature are not systematically applied in various pollen morphological studies, leading to different nomenclatural practices in different pollen identification keys. There are, thus, ample possibilities for unclarity and confusion for Quaternary palynologists.

\section{Nomenclatural problems in the palynological practice}

In daily practice, Quaternary palynologists identify fossil pollen with several pollen identification keys and (hopefully) a collection of pollen reference slides. Since the keys use different pollen morphological names (see above), nomenclatural confusion is the logical outcome when several keys are indiscriminately combined. In our previous article (JOOSTEN \& De KLERK 2002) we review the confusions and misunderstandings that arise.

1: When bare taxon names are used for pollen types, identical names are used for two different objects (i.e. plant taxa and pollen types). This is especially a nuisance, when a full reciprocal coverage is failing, as, for example, with Asteraceae tubuliflorae pollen that is not produced by all Asteraceae tubuliflorae taxa.

2: Two different pollen types might have the same name in one identification key, e.g. the Plumbaginaceae pollen type of Fægri \& IverSEN (1989) and of BEUG (2004) that is produced by the pollen morphologically dimorphic $A r$ meria and Limonium.

3: The counterpart is that the same pollen type has two different names in the same pollen key, e.g. Limonium vUlgare type A and Limonium HUMILE TYPE of MOORE et al. (1991).

4: Different pollen types may have identical names in different keys. This is the case with the Silene VUlgaris type of Moore et al. (1991) that is morphologically differently described and is ascribed to other producing taxa than the Silene vulgaris type of Punt et al. (1995). In practice, morphological descriptions of pollen types change when pollen keys are revised, which leads to new morphological types although the names remain the same (cf. Moore \& WebB 1978, Moore et al. 1991, FÆGRI \& IVERSEN 1950, 1964, 1975, 1989, FÆGRI 1993, BEUG $1961,2004)$. An example from the various keys of F⿸尸GRI \& IVERSEN is presented in our previous study (Joosten \& De KLeRK 2002: 35).

5: Morphologically different types may have similar names in different keys. The pollen type Chenopodiaceae of Fegri \& Iversen (1989) (in their definition also including pollen of Amaranthaceae) is described as 'usually' containing more than 50 pores and, thus, is a different morphological object than the pollen type Chenopodiaceae and Amaranthaceae of Moore et al (1991) that is described as having 'usually' more than 40 pores, or the CHENOpodiaceae P.P., Amaranthus of Beug (2004) that is defined as having in general more than 40-50 pores, but at least (25)35 pores. Similar 
problems occur when taxonomical pollen types are not described in their full morphological diversity, e.g. Selaginella Selaginoides spores that are described both as single grains and as tetrads by Moore et al. (1991; thus using the same name for two different morphological types), whereas the Selaginella Selaginoides TyPe of Punt \& Blackmore (1991) and SElaGINELLA of FÆGRI \& IVERSEN (1989) are only described as single grains.

6: One key may adopt a pollen type from another key but give it a different name. Examples for this are the TYPHA ANGUSTIFOLIA TYPE and the CAnnabis type of Moore et al. (1991) who renamed the SPARgANIUM EMERSUM TYPE and Humulus lupulus type of Punt (1976) and Punt \& Clarke (1984) respectively. Additional mistakes arise when such adoptions are incomplete, e.g. the TyPHA LATIFOLIA TYPE that PunT (1976) described as a quadratical plain and (less frequently) as a linear arrangement of four grains. Though Moore et al. (1991) refer to the key of PunT (1976) they do not mention the linear possibility, thus giving their TYPHA LATIFOLIA TYPE a slightly different pollen morphological content. Another example is the key of Moore et al. (1991) claiming to have derived their RuMEX ACETOSELla TYPE and OXYRIA TYPE from PunT et al. (1988), whereas the latter only use (at a subkey level) RuMEX ACETOSELla and OXYRIA.

7: Identical or similar pollen types might be described with different properties in different keys and publications. The differentiation between pollen of tree birches and shrub birches, for example, can be made by means of morphological features (e.g. TerasmäE 1951, Praglowski 1962, Punt et al. 2003) and by means of (to some extent mutually incompatible) size-statistical methods (e.g. ENEROTH 1951, Birks 1968, Usinger 1975, ANDERSEN 1980, cf. MÄKELÄ 1996).

8: A problem we did not consider in our original publication (Joosten \& De KLeRK 2002) is that some palynological studies use such unclear nomenclature that it is impossible to understand what palynomorphological entity is meant. An example occurs in the revised FUKAREK pollen diagrams in the publication that started the debate (De KLERK 2004a): FuKAREK originally presents a pollen type "Plant.". We do not know whether he abbreviated Plantago, Plantago lanceolata, or Plantaginaceae, i.e. there are three different morphological possibilities with different plant taxonomical interpretations.

These examples show that in palynological literature it is impossible to clearly interpret pollen data as long as it is unclear which concrete pollen morphological description has been used to identify a pollen type.

\section{A plea for clarity}

Our major conclusions (cf. JoOsten \& DE KLERK 2002) are that the differences between the concepts of a pollen type and that of a plant taxon require them to be treated differently, that a cohering pollen type nomenclature does not exist, and that therefore palynological publications are susceptible to confusion and misinterpretation.

Our main plea, therefore, is for clarity. Since a cohering and widely accepted pollen morphological nomenclature is non-existent, following a specific nomenclature cannot be demanded. We feel that in nomenclature the actual name is of minor importance as long as it is clear what it stands for, or as we put it in our original publication (JoOsTen \& De KLERK 2002: 38-39): 'I do not care what you call it, as long as I know what you mean'.

In order to provide the necessary clarity on pollen type nomenclature in palynological publications, we provided several suggestions (Joosten \& De KleRK 2002). These include:

1: Names of pollen types should indicate that they deal with pollen morphological categories, not with plant taxonomical entities. This can be done by putting pollen type names in SMALL CAPITALS and refrain from using italics.

2: Pollen type nomenclature should refer to characteristics of pollen grains, and not to names of plant taxa. Names of pollen types should, therefore, not change when plant taxonomic and/or plant nomenclatural viewpoints change.

3: Inspite of numerous nomenclatural problems with the pollen morphological literature (see above), it seems unwise to replace the exis- 
ting pollen type names with other (artificial) names, since this will only lead to more confusion. We ourselves made that mistake when we proposed to use the suffix 'type' for all pollen morphological entities regardless their names in pollen morphological literature (DE KLERK et al. 1997), thus introducing a new concept of the suffix 'type'. That proposal was rightfully criticised by BEUG (2004).

4: To avoid confusion, reference should always be given to all identified pollen types individually when several pollen keys are used in combination. This can be easily done by providing an abbreviation for pollen types in pollen diagrams, e.g. (f) for pollen types described by FÆGRI \& IVERSEN (1989), (m) for Moore et al (1991), (p) for the Northwest European Pollen Flora, and (b) for Beug (2004). Types that are not identified after pollen morphological reference literature should be individually listed and described.

Our further suggestions plead for a careful use of terms like "undiff(erentiated)" and "cf.", a careful descriptions of unknown and indeterminable pollen grains, and an avoidance of terms like "indet(erminable)", "varia", and "sp.".

\section{A plea for scientific freedom}

We do not want to impose our proposals on the international scientific community as a new set of rules for pollen type nomenclature. We consider our proposals merely as a practical alternative to avoid a widespread (predominantly still unrecognised) methodical confusion. Only the future will tell whether our proposals will develop into an internationally widespread nomenclatural practice, or whether they will sink back into oblivion. We feel that we formulated sound scientific grounds to abandon traditional conventions and to distinguish clearly between 'pollen types' and 'plant taxa'.

Science should always be open for critical reappraisal and scientific debate. Our proposal is not a violation of clearly defined pollen nomenclatural rules, but merely a practical modification of not unambiguously defined and applied conventions. Our alternative is indeed in that respect 'unconventional', but not a violation of scientific principles.
Our alternative is accepted by several scientific journals, including the Greifswalder Geographische Arbeiten (DE KLERK et al. 2001, Theuerkauf 2003), Internationale Archäologie (De Klerk 2004b), Suo (KaffKe et al. 2002), Archiv für Naturschutz und Landschaftsforschung (De Klerk 2005, 2006), Mires and Peat (Gaudig et al. 2006), Zeitschrift für Geologische Wissenschaften (De KLERK \& Helbig 2006), Quaternary Science Reviews (DE KLERK et al. 2007) and the Review of Palaeobotany and Palynology (DE KLERK 2002, BARTHELMES et al. 2006).

Our original article (Joosten \& De Klerk 2002) ranked 2 in the list of most downloaded articles from Internet of the Review of Palaeobotany and Palynology in the year after its publication, and remained at high places for several years. We assume, therefore, that it is widely distributed within the international palynological community. Until now, no serious scientific critique has reached us (with the exception that our proposals are unusual, i.e. 'unconventional', which hardly can be considered to be a scientific argument). A statement we did not make was severely criticised by Hesse et al. (2003), but since they also systematically misspelled the name of one of us we doubt that they have actually seen our article.

The differentiation between pollen types and plant taxa is to our opinion necessary for an unambiguous development of palynological science. We, therefore, hope that scientific journals will accept and allow the use of our 'unconventional' ideas and methods. We invite all scientists to participate in the debate on the character of pollen types.

\section{Acknowledgments}

We want to thank Eiszeitalter und Gegenwart for giving us the opportunity to present our viewpoints. M. MinKE kindly corrected the German summary.

\section{References}

ANDERsen, S.T. (1979): Identification of wild grass and cereal pollen. - Danm. geol. Unders., Årbog 1978: 69-92; Copenhagen.

ANDERSEN, S.T. (1980): Early and Late Weichselian 
chronology and birch assemblages in Denmark. - Boreas, 9: 53-69; Oslo.

Berglund, B.E. \& RalsKa-Jasiewiczowa, M. (1986): Pollen analysis and pollen diagrams. - In: Berglund, B.E. (ed.): Handbook of Holocene Palaeoecology and Palaeohydrology: 455-484; Chichester (Wiley).

Beug, H.-J. (1961): Leitfaden der Pollenbestimmung.- Lieferung 1.: $63 \mathrm{~S}$.; Stuttgart (Fischer).

Beug, H.-J. (2004): Leitfaden der Pollenbestimmung für Mitteleuropa und angrenzende Gebiete. - 542 S.; München (Pfeil).

BIRKs, H.J.B. (1968): The identification of Betula nana pollen - New Phytol., 67: 309-314; Cambridge.

BIRKS, H.J.B. (1973): Past and present vegetation of the Isle of Skye: a palaeoecological study. -415 S.; Cambridge (Cambridge university press).

BIRKS, H.J.B. \& BIRKs, H.H. (1980): Quaternary palaeoecology. - 289 S.; London (Edward Arnold).

Bóros, A. \& JÁraI-Komlodi, M. (1975): An atlas of recent European moss spores. - 466 S.; Budapest (Akadémiai Kiadó).

Chanda, S. \& Erdtman, G. (1965): Some graminoid pollen types and their bearing on micropalaeobotany. - J. Palynology, 1: 32-37; Lucknow.

De Klerk, P. (2002): Changing vegetation patterns in the Endinger Bruch area (Vorpommern, NE Germany) during the Weichselian Lateglacial and Early Holocene. - Rev. Palaeobot. Palynol., 119: 275-309; Amsterdam.

De Klerk, P. (2004a): Vegetation history and landscape development of the Friedländer Große Wiese region (Vorpommern, NE Germany) inferred from four pollen diagrams of Franz Fukarek. - Eiszeitalter u. Gegenw., 54: 73-96; Hannover.

De KLeRK, P. (2004b): Changes in vegetation and environment at the Lateglacial-Holocene transition in Vorpommern (Northeast Germany). - Internat. Arch.-ATSK, 5: 27-42; Rahden.

De KLERK, P. (2005): A pollen diagram from the Ahlbecker Seegrund (Ueckermünder Heide, Vorpommern, NE Germany) from the legacy of Franz Fukarek. - Archiv. Natursch. Landschaftsforsch., 44(3): 93-108; Remagen-Oberwinter.

De Klerk, P. (2006): Lateglacial and Early Holocene vegetation history near Hennigsdorf (C Brandenburg, NE Germany): a new interpretation of palynological data of Klaus Kloss. - Archiv. Natursch. Landschaftsforsch., 45(1): 23-35;
Remagen-Oberwinter.

De Klerk, P. \& Helbig, H. (2006): A pollen diagram from a kettle-hole near Horst (Vorpommern, NE Germany) covering the later part of the Weichselian Lateglacial. - Z. geol. Wiss., 34: 379-387; Berlin.

De Klerk, P., Janssen, C.R., Joosten, J.H.J. \& TöRnQvist, T.E. (1997): Species composition of an alluvial hardwood forest in the Dutch fluvial area under natural conditions (2700 cal year BP). - Acta Bot. Neerl., 46: 131-146; Oxford.

De Klerk, P., Helbig, H., Helms, S., Janke, W., Krügel, K., Kühn, P., Michaelis, D. \& Stolze, S. (2001): The Reinberg researches: palaeoecological and geomorphological studies of a kettle hole in Vorpommern (NE Germany), with special emphasis on a local vegetation during the Weichselian Pleniglacial/Lateglacial transition. - Greifswalder Geogr. Arb., 23: 43-131; Greifswald.

De Klerk, P., Couwenberg, J. \& Joosten, H. (2007): Short-lived vegetational and enviromental change during the Preboreal in the Biebrza Upper Basin (NE Poland). - Quat. Science Rev., 26; Oxford [in press].

ENEROTH, O. (1951): Undersökning rörande möjligheterna att $\mathrm{i}$ fossilt material urskilja de olika Betula-arternas pollen. - Geol. För. Stockholm Förhandl., 73: 343-405; Stockholm.

ERdtMan, G. (1947): Suggestions for the classification of fossil and recent pollen grains and spores. - Sven. Bot. Tidskr., 59: 49-58; Stockholm.

FÆGRI, K. (1993): Bestimmungsschlüssel für die nordwest-europäische Pollenflora. Extract from: FÆGRI \& IVERSEN (1989), translated by E. LANGE. - 85 S.; Jena (Fischer).

FÆGRI, K. \& IVERSEN, J. (1950): Textbook of modern pollen analysis. - 169 S.; Copenhagen (Munksgaard).

Fłgri, K. \& Iversen, J. (1964): Textbook of pollen analysis. $-2^{\text {nd }}$ edition: 237 S.; Copenhagen (Munksgaard).

Fegri, K. \& Iversen, J. (1975): Textbook of pollen analysis. $-3^{\text {thd }}$ edition: 295 S.; Copenhagen (Munksgaard).

FÆgri, K. \& Iversen, J. (1989): Textbook of pollen analysis. $-4^{\text {th }}$ edition: 328 S.; Chichester (John Wiley \& sons) [revised by FÆGRI, K., KaLAND, P.E. \& Krzywinski, K.].

Gaudig, G., Couwenberg, J. \& Joosten, H. (2006): 
Peat accumulation in kettle holes: bottom up or top down? - Mires Peat, 1: article 06 (http: //www.mires-and-peat.net).

Greuter, W., McNeill, J., Barrie, F.R., Burdet, H.M., Demoulin, V., Filgueiras, T.S., Nicolson, D.H., Silva, P.C., Skog, J.E., Trehane, P., Turland, N.J. \& Hawksworth, D.L. (2000): International code of botanical nomenclature (Saint Louis code) adopted by the Sixteenth International Botanical Congress St. Louis, Missouri, July-August 1999. - 474 S.; Koenigstein (Koeltz).

Hesse, M., Weber, M. \& Zetter, R. (2003): The importance of being an ultrastructurally experienced palynologist. - Palynos, 26/2: 1-7; Tempe.

HJelmroos, M. (1991): Evidence of long-distance transport of Betula pollen. - Grana, 30: 215228; Oslo.

HJelmroos, M. \& Franzén, L.G. (1994): Implications of recent long-distance pollen transport events for the interpretation of fossil pollen records in Fennoscandia. - Rev. Palaeobot. Palynol., 82: 175-189; Amsterdam.

Holmgren, P., Lanjouw, J. \& Stafleu, F.A. (1990): Index herbariorum: a guide to the location and contents of the world's public herbaria. Part 1: the herbaria of the world. $-8^{\text {th }}$ edition: $693 \mathrm{~S}$.; New York (New York Botanical Garden).

Hooghiemstra, H. \& Van Geel, B. (1998): World list of Quaternary pollen and spore atlases. - Rev. Palaeobot. Palynol., 104: 157-182; Amsterdam.

Iversen, J. (1936): Sekundäres Pollen als Fehlerquelle. Eine Korrektionsmethode zur Pollenanalyse minerogener Sedimente. - Dan. Geol. Unders. IV. Række, 2: 3-24; Copenhagen.

Iversen, J. \& Troels-Smith, J. (1950): Pollenmorfologiske Definitioner og Typer/Pollenmorfologischer Definitionen und Typen. - Dan. Geol. Unders. IV. Række, 3/8: 1-52; Copenhagen.

Iversen, J. \& Troels-Smith, J. (1980): Pollen morphological definitions and types (translation of Iversen \& Troels-Smith 1950). - Dan. Geol. Unders., Årbog 1980: 5-44; Copenhagen.

Joosten, H. \& De Klerk, P. (2002): What's in a name? Some thoughts on pollen classification, identification, and nomenclature in Quaternary palynology. - Rev. Palaeobot. Palynol., 122: 2945; Amsterdam.

Joosten, H. \& De KleRK, P. (2007a): DAMOCLES: a DAshing Monolith Cutter for fine sectioning of peats and sediments into LargE Slices. - Boreas, 36: 76-81; Oslo.

Joosten, H. \& De KLERK, P. (2007b): In search of finiteness: the limits of fine resolution palynology of Sphagnum peat. - The Holocene, 17; London [in press].

Joosten, J.H.J. \& VAN DEN BRInK, L.M. (1992): Some notes on pollen entrapment by rye (Secale cereale L.). - Rev. Palaeobot. Palynol., 73: 145151; Amsterdam.

KaffKe, A. \& Kaiser, K. (2002): Das Pollendiagramm „Prerower Torfmoor“ auf dem Darß (Mecklenburg-Vorpommern): neue Ergebnisse zur holozänen Biostratigraphie und Landschaftsgeschichte. - Meyniana, 54: 89-112; Kiel.

Kaffke, A., Matchutadze, I., Couwenberg, J. \& Joosten, H. (2002): Early $20^{\text {th }}$ Century Russian peat scientists as possible vectors for the establishment of Calluna vulgaris in Georgian Sphagnum bogs. - Suo, 53: 61-66; Helsinki.

Laursen, K., Holm, E. \& Sørensen, I. (1997): Pollen as a marker in migratory warblers, Sylviidae. -Ardea, 85: 223-231; Leiden.

Lorenz, S. \& Schult, M. (2004): Das Durchbruchstal der Mildenitz bei Dobbertin (Mecklenburg) - Untersuchungen zur spätglazialen und holozänen Talentwicklung an Terrassen und Schwemmfächern. - Meyniana, 56: 47-68; Kiel.

MäKELÄ, E.M. (1996): Size distinctions between Betula pollen types - a review. - Grana, 35: 248-256; Oslo.

Moore, P.D. (1980): The reconstruction of the Lateglacial environment: some problems associated with the interpretation of pollen data. - In: LowE, J.J., Gray, J.M. \& Robinson, J.E. (eds.): Studies in the Lateglacial of North-west Europe: 151-155; Oxford (Pergamon Press).

Moore, P.D. \& Webb, J.A. (1978): An illustrated guide to pollen analysis. - 133 S.; London (Hodder \& Stoughton).

Moore, P.D., Webi, J.A. \& Collinson, M.E. (1991): Pollen analysis. - 216 S.; Oxford (Blackwell Scientific Publications).

Praglowski, J.R. (1962): Notes on the pollen morphology of Swedish trees and shrubs. - Grana Palynol., 3: 45-65; Stockholm.

Punt, W. (ed.) (1976): The Northwest European Pollen Flora I. - 145 S.; Amsterdam (Elsevier). 
Punt, W. \& Blackmore, S. (eds.) (1991): The Northwest European Pollen Flora VI. - 275 p.; Amsterdam (Elsevier).

Punt, W. \& Clarke, G.C.S. (eds.) (1980): The Northwest European Pollen Flora II. - 265 S.; Amsterdam (Elsevier).

Punt, W. \& Clarke, G.C.S. (eds.) (1981): The Northwest European Pollen Flora III. - 138 S.; Amsterdam (Elsevier).

Punt, W. \& Clarke, G.C.S. (eds.) (1984): The Northwest European Pollen Flora IV. - 369 S.; Amsterdam (Elsevier).

Punt, W., Blackmore, S. \& Clarke, G.C.S. (eds.) (1988): The Northwest European Pollen Flora V. - 154 S.; Amsterdam (Elsevier).

Punt, W., Blackmore, S., Hoen, P.P. \& Stafford, P.J. (eds.) (2003): The Northwest European Pollen Flora, VIII. - 183 S.; Amsterdam (Elsevier).

Punt, W., Hoen, P.P. \& Blackmore, S. (eds.) (1995): The Northwest European Pollen Flora VII. - 275 S.; Amsterdam (Elsevier).

ScAmonI, A. (1955): Über den gegenwärtigen Stand unseres Wissens vom Pollenflug der Waldbäume. - Z. Forstgenetik Forstpflanzenz., 4: 145-149; Frankfurt Main.

Stafleu, F.A. (1967): Palynology, nomenclature and terminology. - Rev. Palaeobot. Palynol., 3: 15-26; Amsterdam.

Stafleu, F.A. \& Cowan, R.S. (1976): Taxonomic literature: a selective guide to botanical publications and collections with dates, commentaries and types. - Vol. 1: A-G. - 1136 S.; Utrecht (Bohn, Scheltema \& Holkema).
Terasmäe, J. (1951): On the pollen morphology of Betula nana. - Svensk Bot. Tidskr., 45: 358-361; Uppsala.

Theuerkauf, M. (2003): Die Vegetation NO-Deutschlands vor und nach dem Ausbruch des Laacher See-Vulkans (12880 cal. BP). - Greifswalder Geogr. Arb., 29: 143-189; Greifswald.

Usinger, H. (1975): Pollenanalytische und stratigraphische Untersuchungen an zwei SpätglazialVorkommen in Schleswig-Holstein. - Mitt. Arbeitsgemeinsch. Geobot. Schleswig-Holstein Hamburg, 25: 1-183; Kiel.

VAN DER HAMmen, T. (1956): A palynological systematic nomenclature. - Bol. Geol., 4: 63-101; Bogotá.

VAN DER KNAAP, W.O. (1987): Long-distance transported pollen and spores on Spitsbergen and Jan Mayen. - Pollen Spores, 29: 449-454; Paris.

VAN DER Woude, J.D. (1983): Holocene paleoenvironmental evolution of a perimarine fluviatile area. Geology and paleobotany of the area surrounding the archeological excavation at the Hazendonk river dune (Western Netherlands). - Anal. Praehist. Leidensia, 16: 1-124; Leiden.

VAn Geel, B. \& Grenfell, H.R. (1996): Green and blue-green algae 7A - Spores of Zygnemataceae. - In: Jansonius, J. \& McGregor, D.C. (eds.): Palynology: principles and applications: 173-179; Salt Lake City (AASP Foundation).

Vuorela, I. (1972): Tap-water and unfiltered air as sources of error in pollen analysis. - Memoranda Soc. Fauna Flora Fennici, 48: 49-54; Helsinki. 